NBER WORKING PAPER SERIES

\title{
INTERNATIONAL MIGRATION IN THE LONG-RUN: POSITIVE SELECTION, NEGATIVE SELECTION AND POLICY
}

Timothy J. Hatton

Jeffrey G. Williamson

Working Paper 10529

http://www.nber.org/papers/w10529

\author{
NATIONAL BUREAU OF ECONOMIC RESEARCH \\ 1050 Massachusetts Avenue \\ Cambridge, MA 02138
}

May 2004

The Keynote Address to the 36th Kiel Week Conference on Labor Mobility and the World Economy, Kiel Institute for World Economics, Kiel, Germany (June 21-22, 2004) to be delivered by Williamson. The paper draws heavily on our forthcoming book World Mass Migration: Two Centuries of Policy and Performance. Williamson acknowledges with pleasure financial support from the National Science Foundation SES0001362, and the work environment at the Australian National University Research School of Social Sciences and the University of Wisconsin Economics Department, where this was written while he was on leave from Harvard. The views expressed herein are those of the author(s) and not necessarily those of the National Bureau of Economic Research.

C2004 by Timothy J. Hatton and Jeffrey G. Wiliamson. All rights reserved. Short sections of text, not to exceed two paragraphs, may be quoted without explicit permission provided that full credit, including (C) notice, is given to the source. 
International Migration in the Long-Run: Positive Selection, Negative Selection and Policy

Timothy J. Hatton and Jeffrey G. Williamson

NBER Working Paper No. 10529

May 2004

JEL No. F22, J1, O1

ABSTRACT

Most labor scarce overseas countries moved decisively to restrict their immigration during the first third of the 20th century. This autarchic retreat from unrestricted and even publicly-subsidized immigration in the first global century before World War I to the quotas and bans introduced afterwards was the result of a combination of factors: public hostility towards new immigrants of lower quality, public assessment of the impact of those immigrants on a deteriorating labor market, political participation of those impacted, and, as a triggering mechanism, the sudden shocks to the labor market delivered by the 1890 s depression, the Great War, postwar adjustment and the great depression. The paper documents the secular drift from very positive to much more negative immigrant selection which took place in the first global century after 1820 and in the second global century after 1950, and seeks explanations for it. It then explores the political economy of immigrant restriction in the past and seeks historical lessons for the present.

Timothy J. Hatton

Department of Economics

Australian National University

Canberra, Australia

hatton@coombs.anu.edu.au

Jeffrey G. Williamson

Department of Economics

Harvard University

Cambridge, MA 02138

and NBER

jwilliam@kuznets.fas.harvard.edu 


\section{Prologue}

The autarchic retreat from unrestricted and even subsidized immigration in the first global century before World War I to the quotas and bans afterwards was the result of a combination of factors: public hostility towards new immigrants of lower quality, public assessment of the impact of those immigrants on a deteriorating labor market, political participation of those impacted, and, as a triggering mechanism, the sudden shocks to the labor market delivered by the 1890 s depression, the Great $\operatorname{War}^{1}$ and postwar adjustment. The United States led the way with quotas in the 1920s, and the great depression helped persuade others to follow (e.g. South African quotas in 1930, Brazilian quotas in 1934, and tough restrictions by Australia in 1930, New Zealand in 1931, and Canada in 1932). This paper documents the secular drift from very positive to much more negative immigrant selection which took place in the first global century after 1820 and in the second global century after 1950. It then seeks explanations for it. Finally, it explores the political economy of immigrant restriction in the past and seeks historical lessons for the present.

\section{Immigrant Policy and Immigrant Prejudice}

\section{Backlash: Attitudes Toward Immigrants in the First Global Century}

Public attitude towards immigration became increasingly negative as North America moved in to the long and deep depression of the 1890s, in part as a response to the imagined or real economic threats delivered by the immigrant flood. When asked for their opinions by state labor bureau interviewers in the middle of the 1890s depression, here is how some workingmen in the Midwest responded: almost 63 percent of the Kansas wage-earners surveyed in 1895 thought immigration should be restricted and another 24 percent thought it should be outright suppressed, adding up to 87 percent who wanted to retreat from the free-immigration status quo; almost 68 percent of the Kansas wage-earners surveyed in 
1897 thought immigration should be restricted and another 24 percent thought it should be suppressed, adding up to 92 percent favoring a retreat from the status quo; in 1895, about half of the railway workers and almost 62 percent of the owners of public conveyances surveyed in Michigan thought that immigration hurt their occupation, and more than 92 percent of those Michigan workers favored restriction (Hatton and Williamson 2004: Chp. 8).

The 1890s wasn't the first time that a powerful immigrant backlash had its public expression in America since loud and hostile voices could be heard a half-century earlier when the first great immigration waves pounded US labor markets. The first immigration surge into the United States which occurred in the three decades following 1820 turned out to be the biggest. At the start of the boom in 1820 , the US was a nation of natives and the immigration rate was only 1 per thousand. By 1845-1846 and even before the Irish famine, the immigration rate had soared to 11.2 per thousand (Chickering 1848 : Table III, 14). By 1850 the immigration rate was more than 15 per thousand, a figure never to be exceeded even in the much-cited pre-World War I boom. ${ }^{2}$ The surge was driven by American growth and settlement, by declining trans-Atlantic steerage costs, by declining passenger costs from European interior to port, by industrial revolutions in Europe (helping to release poverty constraints), and, of course, by the great Irish famine. The share of the foreign-born in the US resident population was 9.7 percent in 1850, 13.1 percent in 1860 and 14 percent in 1870 (US Department of Commerce 1975: 8, 117-18). While these foreign-born shares were certainly enormous by the standards of that time, note that the 1850 figure is exceeded by those for North American and Western Europe today (Table 1).

But it wasn't just a rise in the quantity of immigrants that distinguished this first and biggest surge, since their quality fell too: by the 1850s, US immigrants had become increasingly unskilled as declining passenger costs and economic development back home brought overseas emigration within

\footnotetext{
${ }^{1}$ In addition, the impact of the sinking of the Lusitania in 1915 helped make for anti-European public sentiment.

${ }^{2}$ Ferrie (1999: 35). The immigration rate increased by more than seven times between the early 1820s and the early 1840 s, even before the big leap to 15 per thousand in 1850. The US immigration rate averaged "only" about 10 per thousand during the 1901-1910 boom decade (Hatton and Williamson 1998: Table 2.1).
} 
reach of much poorer, severely capital-constrained Europeans. So, how did Americans respond to the rise in immigrant quantity and the fall in immigrant quality?

"The pressures immigration placed on labor markets, particularly in the urban Northeast, produced a remarkable backlash in the 1850s. The first response of native workers was increased labor militancy ... The second response was political: increasing support for those who preached the nativist creed ... The popular press took up the anti-immigrant cry with equal fervor: an editorial in the Philadelphia Sun asserted that 'the enormous influx of foreigners will in the end prove ruinous to American workingmen"” (Ferrie 1999: 162-3).

The economics underlying that Philadelphia Sun editorial and the Know-Nothing political party rhetoric is pretty obvious: a glut in the labor supply lowered the unskilled wage relative to profits and land rents. Since capital and land were held by those at the top of the distribution pyramid, immigration-induced labor supply growth must have created more inequality and the demise of immigration would have created less, ceteris paribus. In addition, since immigrants were more unskilled than the native-born, immigration must have raised the premium on skills over the common laborer's wage as skills got relatively scarce and the demise of immigration would have reduced the premium on skills as they got relatively abundant, ceteris paribus. However, few native workers were so skilled that they might have been complements to the unskilled, but rather most were near-substitutes for unskilled. Immigrationinduced changes in skill premia and earnings distributions would be a problem for the next century, not this one.

The Know-Nothings, or the Order of the Star-Spangled Banner, had about a million followers in 1854. All white males had the vote in the US at that time, and these numbered 5.7 million. Thus, this third party was able to get more than a sixth of the potential voters, and in only two years! The Know-Nothings elected eight state governors, perhaps one hundred congressmen, and the mayors of Boston, Philadelphia and Chicago (Ferrie 1999: 162), an impressive achievement. 


\section{Backlash: Attitudes Toward Immigrants Today}

Negative public opinion is on the rise today too, as the quantity of immigrants entering OECD labor markets surged and, as we shall see, their quality fell. The rise in quantity has been impressive, as Table 1 confirms. When President John F. Kennedy wrote his book A Nation of Immigrants in 1964, it was not. But the migrant stock as a share of the local population rose in North America from 6 to 13 percent between 1965 and 2000, more than a doubling. Western Europe experienced an even bigger increase, from 3.6 percent in 1965 to 10.3 percent in 2000, a near tripling.

How has public opinion responded to the rise in quantity and the fall in quality of immigration this time? A 1995 international survey asked whether immigration should be reduced in their country, where a score of 3 meant "remain the same," 4 meant "reduce a little" and 5 meant "reduce a lot." The figures for three big immigrating countries were Germany 4.2, Britain 4.1 and the US 3.9 - ranging between "reduce a little" and "reduce a lot" (O'Rourke and Sinnott 2004: Table 1; see also Mayda 2003). Furthermore, these responses were, like those in the 1850s, given during boom times in host country labor markets. One can well imagine what they would be now as the OECD struggles out of the recent slump, perhaps as hostile as were those Midwest workers in the middle of the 1890s depression. While the labor market effects of immigration are again an issue, fiscal effects matter today as well, and they matter far more than in 1850 s or even in the 1890 s when governments were much smaller and immigrants were never a big net fiscal burden or bonus.

Voters in rich countries may be hostile towards immigrants and immigration for both economic and non-economic reasons. Racism, xenophobia and nationalist sentiment can push citizens to vote for immigration restriction. O'Rourke and Sinnott (2004) find that hostility towards immigrants in 1995 had much of its source in this kind of sentiment. They also find that economic motives help explain attitudes towards immigrants and immigration and in predictable ways: it is the unskilled worker in rich countries who has the most negative sentiment; and the unskilled worker's negative sentiment is much stronger in more egalitarian countries (e.g., more so on the European continent than in the US). But the more relevant question is how much of the recent rise in immigrant hostility is driven by a rise in racism, xenophobia 
and nationalist sentiment? The 1995 survey can not answer this question, but history will, as we shall see. Our strong prior, however, is that it is changing economic conditions and changing quality of the immigrants that drives changing voter attitude.

\section{Political Action at the End of the First Global Century}

What was the impact of the immigrant backlash a century ago? New world host countries gradually closed their doors to immigrants after the 1890 s. The doors did not suddenly slam shut on American immigrants when the United States Congress overrode President Wilson's veto of the Immigrant Literacy Act in February 1917, or when it passed the Emergency Quota Act of May 1921, since there was plenty of precedent and warning. Over the half-century prior to the Literacy Act, the United States had been imposing restrictions on what had been free immigration (e.g., contract labor laws, Chinese exclusion acts, excludable classes, head taxes, and so on). And the United States was hardly alone. Argentina, Australia, Brazil, and Canada enacted similar measures, although the timing was sometimes different, and the policies often took the form of an enormous drop in, or even disappearance of, large immigrant subsidies rather than a move to outright exclusion. Thus, travel and job search subsidies disappeared, and offers of free land did too.

The United States illustrates this long political process best. The US debate over immigration restriction started on the House floor in 1895, in the depths of the depression. It continued with the first House roll call in 1897 when 86 percent of the representatives voting went for restriction (Goldin 1994). But American three-legged politics require that the House, the Senate, and the President all agree, and the latter two disagreed with the former. Thus, the debate continued with the creation of the fact-finding Immigration (Dillingham) Commission in 1906, which reported its blockbuster findings in 1911 - that immigrants were low quality, crowded out native born, were poor citizens or even refused citizenship, ${ }^{3}$

\footnotetext{
3 The Dillingham Commission stressed that "new" immigrants were much more frequently temporary and had far higher return migration rates than did the "old" immigrants. By refusing citizenship, they refused assimilation, and thus remained strangers in the United States. This was an important source of hostility, something that is well worth remembering when politicians push for temporary immigration status today.
} 
and contributed to poverty. The debate was resolved when Congress over-rode President Woodrow Wilson's veto in 1917. Recall that the legislation passed was an immigrant literacy requirement, a hurdle that Congress thought would be high enough to keep out low quality immigrants. As it turned out, the hurdle was not high enough, since in the meantime a European schooling revolution had armed young adults pondering the move with the literacy necessary to leap over the US bar (Hatton and Williamson 2004: Chp. 8).

When the underlying fundamentals favor immigration restrictions, usually they are not imposed until an economic crisis occurs, that is, when short run labor market problems are most acute and affected citizens are most verbal. These are precisely the episodes when labor demand slumps, labor markets go slack, potential emigrants postpone their move, and previous immigrants return home disappointed. Under those conditions, net immigration falls to low levels even in the absence of any policy restriction. Indeed, if immigrants flee poor labor market conditions in the host country, then their departure should tend to ease unemployment and prop up sagging earnings of the native-born. Of course, these benign labor market effects never stopped politicians and labor unions from using inflammatory, anti-immigrant rhetoric during industrial crises. Immigrants have always been convenient non-voting scapegoats.

Contrary to the conventional wisdom, therefore, while there was a big regime switch in policy around World War I from unrestricted (and often subsidized) immigration to quotas, there was no big switch in public attitude. Rather, there had been a continued toughening of attitudes towards immigration in the high-wage new world. Attitudes didn't change overnight, but it took a powerful triggering mechanism to convert the underlying anti-immigration sentiment to anti-immigration action.

\section{Positive Selection, Negative Selection and Declining Immigrant Quality}

\section{Declining Immigrant Quality Today}

Annual immigration to North America and Oceania rose gradually to the mid 1970s before surging to a million per year in the 1990s. The absolute numbers were by then similar to those reached 
during the age of mass migration about a century earlier, but they were smaller relative to the destination country populations that had to absorb them. Thus, the US annual immigration rate fell from 11.6 immigrants per thousand in the 1900 s to 0.4 immigrants per thousand in the $1940 \mathrm{~s}$, before rising again to 4 immigrants per thousand in the 1990s. The proportion of the US population foreign born had fallen from a 1910 peak of 15 percent to an all-century low of 4.7 percent in 1970 . The postwar immigration boom increased the foreign-born share to more than 8 percent in 1990 and more than 10 percent in 2000. Thus, the US has today reclaimed two-thirds of the title "a nation of immigrants" after a half-century retreat.

What happened to the United States after World War II also happened world wide. Table 1 reports trends in the foreign-born around the world over the thirty-five years since the mid 1960s. The data are based on country censuses, sources that are likely to be of higher quality than those that report annual immigrant flows, and they deal with unambiguous net permanent moves. The most revealing entries appear in the last four rows of the table. There we see that the foreign-born share in the total population increased by about a third in Oceania between 1965 and 2000 - from 14.4 to 19.1 percent, more than doubled in North America - from 6 to 13 percent, and more than tripled in Europe - from 2.2 to 7.7 percent. North America is defined to exclude emigrating Mexico, so in this case we are talking exclusively about a high-wage immigrant-absorbing region. The same is not true of Europe since the latter is defined to include eastern Europe and the former Soviet Union, two net emigrating regions and, increasingly, a significant source of migrants for the European Union. The foreign-born share in western Europe from 3.6 percent in 1965 to 10.3 percent in 2000, an increase of more than three times, even bigger than for North America. Of course, the addition of unobserved illegals would raise these foreignborn shares, and perhaps even raise their increase over time.

While OECD immigration has surged, the labor market quality of these immigrants has declined. For example, US immigrant males earned 4.1 percent more than native-born men in 1960, but they earned 16.3 percent less in 1990 (Borjas 1999: 1724). Some of this was due to the decline in immigrant educational attainment, but when we control for this effect, the adjusted relative wage still fell by 13.3 
percent over these thirty years. Recently-arrived immigrants always suffer an earnings disadvantage before they assimilate, and that was even true in 1960. But their initial wage relative deteriorated by 24 percentage points over those thirty years. Although the average educational attainment of immigrants improved, it did not increase as rapidly as that of the native-born. The percentage with less that 12 years education (equivalent to less than high school) is greater among immigrants and that gap increased dramatically between 1970 and 1990. For newly-arrived immigrants, that share was 5.6 percentage points higher than for native-born in 1970, but 20.4 percentage points higher in 1990, an increase of almost four times (Hatton and Williamson 2004: Table 15.1). Our guess is that this educational quality decline took place before 1970 and after 1990 as well.

Most of this decline in immigrant "quality" is due to changes in the source country composition of US immigrants (Table 2: Borjas 1999), and it reflects four seismic shifts in world migration patterns by source over the half century since World War II. The first seismic shift involved Europe's decline as an emigrant source: European emigration to North America and Oceania collapsed from 400,000 per annum in the early 1950 s to less than 100,000 per annum in the early 1990 s. Part of this drop can be explained by the resurgence of migration within Europe. To take only one example, the share of Portuguese emigrants moving within Europe rose from a tiny minority of 1.5 percent in 1950-54 to a large majority of 57.1 percent in 1970-74 (United Nations 1979). Migration within Europe (including Turkey) grew rapidly in the early postwar years through guestworker arrangements, particularly in Germany where by 1973 one out of nine workers was foreign-born. Foreign nationals increased from 1.3 percent of the western European population in 1950 to 3.6 percent in 1965 and 10.3 percent 1990 . The 2000 figure might even double if it included the foreign-born that had become naturalized (Stalker 1994: 189-90).

More recently, western and southern Europe have become destinations for immigrants from Asia, the Middle East and Africa, and since the demise of the Soviet Union in the 1990s western Europe has also absorbed immigrants from the east including the former Soviet republics. As a result, annual net immigration into the European Union (EU) rose from 200,000 in the 1980 s to over a million in 1989- 
1993: over the decade between the 1980s and 1990s, EU immigration more than tripled. Indeed, EU immigration now surpasses that of the US and would exceed it by even more if (estimated) illegal immigrants were included.

The second seismic shift involved the transformation of Latin America from a major emigrant destination to a major immigrant source. The Latin American evolution is a mirror image of the European transformation from a major source to a major destination, and it appears to be unique. We have come to expect that poor, low-wage and agrarian countries should send out emigrants, especially during early industrialization, but at some point these countries should start to receive immigrants as they get rich, industrial and high-wage. Latin America is the sole exception to this rule, and the explanation appears to be that the region has an even richer and faster growing neighbor to the north. Since the 1920s, Latin America has never been able to catch up with North American living standards, or even to reduce the gap. Thus, it is hardly surprising that the stock of immigrants in Latin America and the Caribbean who were born outside the region fell from 3.7 million in 1960 to 3 million in 1980, while Latin Americans and Caribbeans residing outside the region increased from 1.9 million to 4.8 million over the same two decades. The magnitude of this change has been really quite phenomenal: Latin America underwent a secular regime switch from hosting (net) 1.8 million foreign-born, to having (net) 1.8 million Latin Americans hosted abroad, a regime switch adding up to a net change of 3.6 million over only two decades!

The changing source of United States immigrants is particularly instructive in illustrating this Latin American migration revolution (Table 2). Whereas only about a fifth (22.2 percent) of all US immigrants came from south of the border in the 1950s, almost half (47.2 percent) did so in the 1990s, the latter about equally split between Mexico and the rest of Latin America and the Caribbean. Mexicans themselves increased their share of US (legal) immigration from almost 12 percent in the 1950s to almost 25 percent in the 1990s. No doubt the measured share would have increased even more had it included 
illegals. The rising role of Mexican-Americans presents a challenge to US assimilation capabilities that probably has no match in its long immigration history (Huntington 2004).

The third seismic shift during the post-war decades involved Asian and African immigrants, whose numbers rose from negligible to a very large flow. Asian migrants to the US have come mainly from India, Pakistan, China, Korea, the Philippines and Vietnam. Europe has undergone the same surge in Asian immigration as well as a surge from Africa and the Middle East. Annual immigration from the developing world into five major European destination countries -- Belgium, Germany, the Netherlands, Sweden and the United Kingdom -- rose from 97,000 in 1975-79 to 225,000 in 1990-93 (United Nations 1997: 32-3). For Germany alone, annual immigration from North Africa and western Asia more than tripled from 20,000 in 1975-79 to 67,000 in 1990-93, while the numbers from Sub-Saharan Africa rose from 1,200 to 22,000 .

The fourth seismic shift involved emigration from eastern Europe. ${ }^{4}$ The movement of European labor from the less industrial and poor east to the more industrial and rich west has a long history that goes back to the industrial revolution almost two centuries ago. Even during the troubled interwar years, migration from Poland and Czechoslovakia to Belgium and France was extensive. In the five years following the end of WWII, something like 12 million ethnic Germans returned to Austria or Germany from Poland, Czechoslovakia and the Soviet Union. When the Soviet Union annexed eastern parts of Poland at the end of the war, some 1.5 million Poles emigrated.

\footnotetext{
${ }^{4}$ A fifth seismic shift involved the Persian Gulf. The development of oil production and exports in the countries bordering the Persian Gulf led to a large labor demand boom which spilled over in to an increasing demand for foreign workers. The rapid job creation appeared in construction, trade and low-skilled service industries, as well as in occupations requiring more highly educated workers, such as teachers, engineers, and doctors. Initially, the rising excess demand for labor was satisfied by importing temporary contract workers from nearby parts of the Arab world, like Egypt, Palestine and Yemen. With the formation of the OPEC cartel and with the continuing increase in world demand for oil, crude oil prices reached unprecedented heights. This price boom raised local income and generated an extraordinary increase in the demand for labor, an excess demand that spilled over in to a demand for foreign workers. While contract workers from other Arab states continued to move to the Persian Gulf, they were soon far outnumbered by the millions of temporary workers from nearly all parts of Asia. The annual flow of Asian workers to the Middle East increased from less than 100,000 in 1975 to nearly one million in 1991, with the sources moving eastward as time went on.
} 
This traditional east-west flow of European migrants was stopped cold by postwar emigration policy in the centrally planned economies (United Nations 2002: 12). Thus, a historically important world migration flow almost ceased for those three or four decades after 1950. Things changed dramatically in the 1980s when Poland and Romania opened up, and they changed even more dramatically when the Berlin Wall fell in November of 1989. Emigration from what came to be called the transition economies increased by five times between 1985 and 1989, from about 240,000 to about 1.2 million. The annual outflows stayed at those high levels until 1993, when they eased off a bit, averaging around 700,000 in 1997 and 1998 (United Nations 2002: Tables 3 and 5). Since illegals from the rest of the world are using Europe's east as a door to its west, these legal migration figures no doubt understate the magnitude of the total immigrant surge in western Europe. In short, Europe seems to have re-established its old east-west migration tradition.

\section{Declining Immigrant Quality Due to Changing Source in the First Global Century}

The current discussion over the impact of shifting immigrant source on the labor market quality of immigrants certainly has its parallel in the pre-1914 era, years that culminated in the influential Dillingham Commission Report and the subsequent country-of-origin quotas imposed a decade later. An ominous comparison, perhaps, but it provides an obvious benchmark. So how do the two eras match up?

The figures for (gross) intercontinental emigration from Europe are plotted as five-year averages in Figure 1. In the first three decades after 1846 the numbers averaged about 300,000 per annum; in the next two decades they more than doubled; and after the turn of the century they rose to over a million per annum. European emigrant sources also changed dramatically. In the first half of the century, the dominant emigration stream was from the British Isles, followed by Germany. A rising tide of Scandinavian and other northwest European emigrants joined these "old" emigrant streams by midcentury. Southern and eastern Europeans followed suit in the 1880s. This "new" emigrant stream from the south and east accounted for most of the rising emigrant totals in the late $19^{\text {th }}$ century. It came first from 
Italy and parts of Austria-Hungary, but from the 1890s it swelled to include Poland, Russia, Spain and Portugal. This shift in country-of-origin implied a decline in immigrant quality as more and more came from low-wage, low-skilled and low-schooled regions.

Observers and voters noted the decline in immigrant quality before World War I, and it became an important issue in debates over policy. So much for political realities, but what was the economic impact of the decline in immigrant quality? In 1909 the wage for the average male immigrant in industry was 6.4 percent lower than for native-born males; a figure comparable with the late 1970s. Male immigrants in 1909 who were newly arrived earned 20.4 percent less than natives, a figure that is also similar to the 1970s. But note this important fact: the variation in immigrant quality by source is five times greater in modern times than it was in the past. Thus, the standard deviation of the log wage across immigrant nationalities was 0.056 in 1909 as compared with 0.295 across immigrant nationalities in 1980 . Stated another way, much of the source country difference in labor market performance is accounted for by the wage gap between 'old' and 'new' immigrants (Hatton 2000: 520-25): the wage gap in 1909 between immigrants from northwest Europe (old) and the rest (new) was 6.7 percent; by contrast, the wage gap in 1980 between Europeans and those from Africa, Asia and South America was 30.7 percent.

Since wage gaps among newly arrived immigrants are much wider in more recent times, the effects of changing nationality mix are potentially more powerful. Between 1873 and 1913, the effect of changing source country composition from high to low quality origin was to reduce the immigrant wage by only 4.7 percentage points (2.3 percentage points after 1893). Between 1940 and 1980, however, source country composition shifts reduced the immigrant wage by 27 percentage points (17 percentage points after 1960). Thus, the decline in immigrant quality in the four decades before 1980 was $m u c h$ greater than that which prevailed in the four decades before World War I. Our guess is that a similar quality decline would characterize the years since 1985. Furthermore, these calculations understate the downward drift in immigrant quality to the extent that it only considers legal immigrants. Illegal immigrants tend to be less skilled and it appears that they have increased in relative importance over the past half century. 


\section{Individual Selection versus Country Source Effects}

What about the selection of immigrants from a given country? According to the Roy model, immigrants should be more negatively selected the higher is the return to skills (and the greater is earnings inequality) at the origin (Borjas 1987). Given that Mexican inequality exceeds American inequality, theory suggests that Mexican emigrants should be unskilled. In terms of observable skills, however, immigrants from Mexico were drawn predominantly from the middle of the distribution, not from the bottom (Chiquiar and Hanson 2002). A good example of this is offered by Table 3 which reports education data for adult migrants in OECD host countries by sending source and for adults in the same sending source countries. While migrants in the OECD have 7.2 more years of education than the adults they left back home, Mexican migrants (mostly in the US) had only 1.2 more years of education than did Mexican adults back home. The data in Table 3 do not adjust for the fact that immigrants are younger than the average adult back home, or for the fact that immigrants may have received some education in host countries after their arrival. However, it is very clear that the gap between mover and stayer is much smaller for Mexicans who are close to the US, and for east Europeans, Balkans and Turks - who are close to the EU. It appears that the revealed weaker positive selection is because as a share of income migration costs decrease sharply with skill level, offsetting the positive selection effects of greater inequality at the source.

Although Latin American immigrants are not, on the whole, negatively selected it seems that they are less positively selected than migrants from poorer and more distant sources. To repeat, high migration costs favor positive selection, and low migration costs favor negative selection. Mexico is close enough to the US, and countries to the immediate east and southeast are close enough to the EU, so that all share lower migration costs and thus can send poorer and less skilled migrants. Greater distances, lower source country inequality, weaker friends and relatives effect and (for the poorest regions) the poverty constraint all imply that US and EU migrants coming from farther away should be more positively selected. So it was that the 1990 share of US immigrants with tertiary schooling was more than three times higher for Asians 
and Africans than it was for Mexicans and Central Americans. And so it was that the gap in education level between movers and stayers was greatest for Asians and Africans (Table 3).

While the United States and other overseas regions faced rising immigrant quantity before World War I, they also faced falling immigrant quality. The OECD is facing falling immigrant quality again today. In both global centuries, it was the shift in source from richer to poorer regions that lowered immigrant quality.

\section{Why the Drift from Highly Positive towards More Negative Selection?}

\section{Selection by Sending Region in the First Global Century}

The emigrants in 1900 were certainly different from those in 1800 . Early $19^{\text {th }}$ century migrations often took place as family groups, intent on acquiring land and settling at some overseas frontier. While many still had rural roots in the late $19^{\text {th }}$ century, the emigrants from any given country were increasingly drawn from cities, towns and urban occupations. Thus, emigrants from Britain in the 1830 s, a country that by then already had undergone a half-century of industrialization, were mainly from non-farm occupations. This industrialization-induced trend was overwhelmed by the shift from old emigrant sources — the industrial leaders, to new emigrant sources — the industrial followers. In short, the $19^{\text {th }}$ century shift in source dominated immigrant selectivity, and it served to lower immigrant quality. So it was that this shift in source left its mark on trends in the occupational composition of United States immigration across the century (Table 4). Thus, the proportion of the immigrants that were unskilled rose from 16 percent in the 1820 s to 55 percent in the 1890 s, while the share that were skilled fell from 61 to 30 percent. The trends from very positive selection to negative selection were probably even more dramatic than these figures suggest, and for two reasons. First, "farmers" were individuals with assets, coming from the middle of the European income distribution. If these are added to the skilled, that share falls from 84 to 42 percent. Second, between the 1820s and the 1890s, the United States underwent an 
industrialization that was the envy of the world. Along the way, the unskilled fell as a share of the resident labor force, and share skilled, professional and commercial increased. Thus, relative to the host country labor force, the quality of the immigrants declined even more spectacularly across the century. The same, of course, has been true over the last half century.

The Immigration Commission concluded that the new immigrants were inferior to the old. True, the Commission failed to allow for the assimilation process when comparing new and old immigrants. But even when such adjustments are made, it appears that significant differences between origin groups remain and that these can be traced largely to their characteristics upon arrival. Drawing on the Commission's evidence, Jenks and Lauck demonstrated that among those admitted in 1899-1909 22 percent of old immigrants but only 9.2 percent of new immigrants were classified as either professional or skilled (1926: 36). They also found that among adults only 2.7 percent of old immigrant arrivals were illiterate compared with 35.8 percent of new immigrants. Jenks and Lauck interpreted this as powerful evidence that immigrant quality had fallen as a result of the shift in immigrant source. Yet, as Table 4 shows, there is little evidence of any decline in the share of immigrants that were classified as having skilled, professional or commercial occupations after the 1870s when new immigrants arrived in such large numbers. ${ }^{5}$ Even so, the immigrants would have declined in quality relative to the host labor force, as it gained in schooling and skills.

Positive or negative selection should be judged relative to the sending or the host country. When it's the former, the discussion is about brain drain. When it's the latter, the discussion is about assimilation. Table 5 offers some proxies describing trends in US population and thus labor force quality after 1870, and in the schooling dimension. School enrollment rates rose from 48.4 in 1870 to 69.9 percent in 1930. Attendance rates (days in school per enrolled student) doubled, from 78.4 in 1870 to 151.7 in 1930. As a result of these educational investments, illiteracy dropped steadily over the six decades, from 20 to 4.3 percent. (In 1900, just six years before the Immigration Commission was formed, 
the US illiteracy rate was 10.7 percent while it was 35.8 percent for "new" immigrants. No wonder concern about low quality immigrants became a public issue.) High school graduates were only 2 percent of all 17 year olds in 1870 , but 8.6 percent in 1910 and 28.8 percent in 1930 . Thus, even if immigrant educational attainment was constant over the period, their relative quality would have declined significantly. Any absolute decline in observed immigrant educational quality must be augmented to reflect an even greater relative decline.

In spite of the unambiguous evidence of declining relative quality, opposing views about the evolution of immigrant quality persisted, but perhaps they can be reconciled by noting two trends that were pushing in opposite directions. On the one hand, immigrants from each country were becoming more skilled and educated as industrialization proceeded and schooling expanded at home (but perhaps not as fast as in the US). On the other hand, the immigrant composition was shifting towards the less developed sending regions. The right question to ask is: What effect did the shift in source-country composition have by itself on average immigrant quality? If we focus only on European males and only on those who reported an occupation, the share skilled and professional fell by 4.3 percentage points between 1873 and 1913 (Hatton 2000: Tables 1 and 4). But had the source-country composition stayed constant, the share skilled and professional would have increased by 2.7 percentage points, a difference of 7 percentage points (-4.3-2.7). More dramatic still, between 1893 and 1913 the share of adult immigrants who were literate (in any language) fell by 4 percentage points whereas it would have increased by more than 6 percentage points if source-country composition had remained constant, a difference of 10 percentage points.

It appears that Jenks and Lauck are vindicated: source-country composition effects reduced immigrant quality by quite a bit, at least according to literacy and occupational status; and they reduced it still more relative to US literacy rates. But how much difference did those attributes make to their labor market performance? That is, did the destination labor market place high value on those home-acquired

\footnotetext{
${ }^{5}$ Paul Douglas (1919) made the same point in his critique of the Commission: specifically, he argued that the proportion skilled among the new immigrants in 1899-1909 was no lower than that among the old immigrants at a
} 
attributes? The decline in immigrant earnings relative to the native born that can be attributed to the changing country of origin has been estimated to be less than 5 percentage points, a decline that was associated mostly with the effects of the shifting source-country composition on the proportions who were literate and skilled (Hatton 2000: 520).

Is a five percent decline in the relative earnings capacity of the immigrant inflow over forty years big or small? Perhaps a comparison with more recent experience might help gauge its impact. Sourcecountry composition effects account for a 26 percentage point fall in the relative earnings of newly of arrived immigrants between 1940 and 1980 (Borjas 1992). This is five times as large as the composition effects on immigrant earnings that occurred between 1873 and 1913. Part of the reason for the big difference is that the earnings gap between the new and old immigrants of the 1960s and 1970s were much larger than those between the new and old immigrants of the 1890s and 1900s. Had the Immigration Commission been able to look forward 70 years they might have had a higher opinion of the new immigrants of their own day.

\section{Were Immigrants Positively Selected? Controlling by Source}

Even if the labor market quality of US immigrants declined as a result of the changing origin, it might still have been true that immigrants were positively selected. Indeed, it is widely believed that international migrants were and are the best and brightest — that on average they are more skilled, more ambitious and more enterprising than those who stay home. Although it may be widely believed, the late $19^{\text {th }}$ century evidence is far from clear-cut. Selection could occur along a number of observable characteristics like education, skill, wealth and family background, but what about unobservable characteristics like ambition, energy and motivation? The issue of selection is further complicated by the fact that we cannot observe how migrants would have done had they stayed in the home country. In addition, are we interested in selection relative to home or host country populations? If the focus is on the political economy of immigration restrictions, then it's the host country that matters. In any case, we

time when they formed the bulk of the inflow. 
don't have the evidence to be very precise about host or home country labor force quality. Given these complications, much of what follows should be viewed as informed speculation.

Inferences about selection can be drawn from immigrant performance in destination labor markets. Given sufficient time to assimilate, those from northwest Europe often achieved higher earnings than the native born. This fact implies that the advantage of positive selection eventually outweighed the initial disadvantage of being an immigrant. Those from southern and eastern Europe may also have been positively selected, but even if they were, the positive selection effect failed to outweigh the immigrant disadvantage since their skills - valuable in the home country - were of much lower value in the destination country. A further piece of evidence comes from second-generation immigrants who inherit some of their parents' characteristics but who do not suffer their initial immigrant disadvantage. Nativeborn workers with one or two foreign-born parents had earnings that were 6.5 percent higher than those with native-born parents (Hatton 1997, 2000; Minns 2000). Second generation immigrants appear to have had an advantage over those with native-born parents, implying an element of inherited positive selection.

What about evidence from immigrant origins? Emigrants before the mid- $19^{\text {th }}$ century -- the pioneers of mass transatlantic migration -- were frequently farmers and artisans. While they were not upper class - like the most powerful merchants and the landed rich, these pioneer migrants were from the middle class of their day. For example, emigrants from the German region of Hesse-Cassel were in 183257 "positively selected because the highest skilled were over-represented. In terms of financial wealth, the emigrant population was negatively selected because the richest were under-represented" (Wegge 2002: 390). Emigrants who moved later in the $19^{\text {th }}$ century reveal similar patterns, Thus, among emigrants from Denmark between 1868 and 1900 craftsmen and artisans were over represented -- their share among emigrants was about twice that among the source population; laborers were under represented even though they were the majority of the emigrants (Hvidt 1975: 113). ${ }^{6}$ Thus, for most countries the poorest

\footnotetext{
${ }^{6}$ The under representation of unskilled laborers among new emigrants was not always true, as the Irish illustrate. Long after the famine, Irish laborers were still 80 percent of male emigrants in 1881 but only 22 percent of the Irish labor force, and 84 percent of female emigrants were servants compared with 33 percent of the population. It appears that the poor Irish found another way out of the poverty trap: the huge post-famine emigrant stock abroad
} 
were under-represented in emigrant flows. Still, the important issue is not whether selection was positive or negative, but whether it became less positive, and strongly so.

\section{Constraints, Incentives and Immigrant Selection}

Low representation of the very poor in immigrant flows is consistent with the view that poverty constrained the volume of emigration from the poorer parts of Europe. It is also consistent with the view that transatlantic migrants were more positively selected than they would have been in the absence of poverty constraints. The very poor had the most to gain by a long distance move to high-wage labor markets, but they were least able to marshal the resources needed to invest in the move. These poverty constraints facing Europe's poor declined over the first global century due to the combined effect of the following forces (Hatton and Williamson 1998; 2004: Chps. 3 and 4): transport revolutions lowered the steerage costs from port to port and lowered the cost of getting from interior to port; the same transport revolutions reduced the time in transit, thus lowering income foregone; industrial revolutions at home raised working class earnings, making it easier for potential emigrants to find the surplus to invest in the move; and previous pioneer emigrants sent pre-paid tickets and other remittances home helping to finance the next wave. As the poverty constraint on immigration was released, positive selection diminished and negative selection increased. This fact helps explain an emigration paradox. The emigration rate was low for poorer European countries and regions, and higher for richer countries and regions. Furthermore, European countries went through emigration life cycles, emigration rates rising, not falling, as industrial revolutions unfolded at home. Since the incentive to move fell as incomes rose at home, it must have been an even bigger decline in constraints that explains this life cycle.

What about incentives? The modern literature on migration suggests that one factor determining immigrant selection is the relative return on skills at home and abroad. If the return to skills is higher in the (rich) destination country than in the (poor) origin country then the skilled have a greater incentive to

generated huge remittances which made subsequent emigration possible for poor and unskilled Irish, long after the famine years. 
emigrate than the unskilled. Was that the case in the $19^{\text {th }}$ century? Truly comparable cross country evidence is sparse for most of the $19^{\text {th }}$ century, but Table 6 presents skill premia for blue collar occupations for four Atlantic regions in 1890. The premium for semi-skilled and skilled workers over the unskilled was considerably larger in the United States than in Great Britain, Germany and Switzerland. Other things equal, this would imply a greater incentive for skilled emigration from these countries. The same was not true of France and Belgium and it may not have been true of less developed, early industrializing, "new" European countries for which we do not have comparable data.

Hard evidence on the skilled premium is almost absent for the early $19^{\text {th }}$ century, but there is a tradition that points out expensive unskilled labor and cheap skills in early industrial US compared with Britain (Habbakuk 1962; Rosenberg 1967). For example, while in the 1820s US skilled machine makers received a wage only 2 percent more than their British counterparts, unskilled US labor manning those machines earned 22 percent more. Thus, compared with the US, the British skill premium was 20 percent higher in the 1820s. Such evidence suggests that, in the absence of poverty constraints, Anglo-American migration should have negatively selected British unskilled labor early in the century. We should repeat the important qualification "in the absence of poverty constraints" since that was the force that probably dominated even in the ante bellum period. Anglo-American migration should have positively selected British skilled labor in the 1890 s after 50 or 60 years of hot-house American industrialization when the skill premium was pushed up so high by an explosion of skilled labor demands. Income incentive (negative selection) and poverty constraints (positive selection) were working against each other early in the century, while they were working together late in the century.

We should also observe systematic differences across destinations that offered different incentives or costs to the migrant. The skill composition of the flows to Canada and the United States were very similar at the turn of the century. New evidence suggests a good reason for this: skill premia were also very similar in the two countries (Green, MacKinnon and Minns 2002: 681). ${ }^{7}$ It seems likely

\footnotetext{
${ }^{7}$ Similarities in the wage distributions are striking: In Canada, the log wage premia for operatives and craft workers over unskilled laborers were 0.14 and 0.39 respectively; in the United States they were 0.19 and 0.40 respectively.
} 
that skill premia were similar in Australia. Yet, British emigrants to Australia were much more skilled compared with those heading for North America (Pope and Withers 1994). Since the costs of migration to Australia were so much larger (even when subsidized), any difference in positive selection favoring Australia was likely to have been driven by poverty constraints (only the best could afford the move) rather than by wage relatives.

What about other streams of mass migration? One puzzle is why Italians from the mezzogiorno (the southern regions of Italy) who crossed the Atlantic typically went to the United States while those from the more industrial north typically went to South America. ${ }^{8}$ On the face of it, this fact seems anomalous since the more literate, skilled and urban northern Italians would seem to be better matched with United States labor markets while the less literate, less skilled and more rural southern Italians would have been better matched with South American labor markets. Historians have argued that those at the bottom of the occupational ladder in the poor and backward mezzogiorno gained most by working as unskilled laborers in cities like New York while those from the north had better opportunities to become middle class entrepreneurs or skilled workers in places like Buenos Aires (Klein 1983; Baily 1983: 296). The costs of migration mattered too, of course: the subsidies for migration to the Sao Paulo coffee plantations were offered exclusively to northern Italians. ${ }^{9}$ But as the coffee boom faded and as living standards in North America outstripped those in South America, all Italian emigrants, from north and south, shifted increasingly to the United States.

Clearly, cultural affinities, location preferences and the friends and relatives effect all influenced who emigrated and where they went. But we can also detect the influence of strong economic forces on immigrant selection. It seems plausible to conclude that while positive selection was driven by wage incentives for British and German emigrants, it was driven more by poverty constraints in the poorer parts

\footnotetext{
${ }^{8}$ Among Italians who went to the United States between 1876 and 1930, 80 percent came from the south; among those who went to Argentina only 47 percent came from the south (Klein 1983: 309).

${ }^{9}$ It is sometimes suggested that Italian flow to the United States was characterized by exceptionally high return migration rates. Although Italian return rates were higher than for most other immigrant groups in the US, they were not much higher than the return rates of the Italians who went to Argentina. Between 1861 and 1914 repatriation rates were 47 percent for the US and 52 percent for Argentina (Baily 1983: 296).
} 
of Europe. It also seems likely that the degree of positive selection differed across destinations: the more distant the destination, the greater the costs of emigration and the more likely immigrants would be positively selected. Finally, to the extent that declining migration costs and a release of the emigration constraint, was the dominant force, positive selection fell and negative selection rose across the first global century.

\section{Policy and the Modern Drift to Low Quality Immigrant Source}

In the first global century, shifts in the source country composition were the result of rising incomes and demographic booms in Europe combined with falling transport costs between sending and receiving regions - forces that were amplified by the friends and relatives effect. These forces slowly reduced positive selection: the really poor could finance the move only late in the first global century, as their incomes at home rose and as the cost of passage fell. The same forces have also been at work in the modern era but policy served to accelerate the demise of positive selection. These policy changes included: the abolition of the country-of-origin quotas that had previously favored Europe; the shift to a worldwide quota; and the emphasis on family reunification over skills as the key criteria for admission. Other OECD countries also opened their doors more widely and experienced shifts in immigrant composition and quality, but the effects have not been as dramatic. For example, as the sources of Canadian immigration widened after the 1960s, immigrant quality fell, but by less than it did in the United States (Baker and Benjamin 1994). Some have argued that the difference can be explained by policy, the Canadian points system selecting immigrants with higher average labor quality (Borjas 1993). Perhaps, but note that the difference is accounted for by one dominant fact: Latin Americans are 47 percent of US immigrants but only 14 percent of Canadian immigrants, and Mexicans account for most of that disparity (Antecol et al. 2003). While this Latin difference may be partly due to immigration policy, it also reflects location.

Distance matters enormously in explaining who migrates to the United States (Clark, Hatton and Williamson 2002). Because of its closer proximity to Latin America and its long land border with Mexico, 
the United States would need an even more skill-selective immigration policy than Canada (or even quotas for Latin Americans) in order to raise immigrant quality to the Canadian level.

\section{Why Do We Care? The Political Economy of Restriction}

What explains the evolution of immigration policy? Increasing racism, xenophobia and widening ethnicity gaps between previous and current immigrants have always been popular candidates. But political economy candidates turn out to have been far more powerful: more immigrants, lower-quality immigrants, the threat of even lower-quality immigrants, crowded-out native unskilled workers, rising inequality, greater awareness of that inequality by the powerful (informed by activist reformers), and greater voting power in the hands of those hurt most -- the working poor.

We now know a lot about the underlying determinants of changing immigration policy between 1860 and 1930 (Goldin 1994; Timmer and Williamson 1998; O’Rourke and Williamson 1999: Chp. 10). The most consistent effect is that immigration policy was slow to change. This was especially true of Brazil and the United States: in the latter case, the result is driven by the $1895-1917$ period which included two decades of public scrutiny and congressional debate, ending in the 1917 Immigration Act and the quotas which followed; and in the former case, the result is driven by the 1890-1920 period when heavily subsidized immigration, financed by fat export earnings generated by high coffee prices, was replaced by restriction and no subsidies when plunging coffee prices generated lean export earnings. It is worth noting that where historical persistence was strongest, the switch in policy, from open to closed, was biggest. Big immigration policy changes typically require long periods of debate, and the longer the debate, the bigger the change.

Measures of macroeconomic conditions -- like unemployment rates -- were, predictably, of little help in accounting for long-run policy changes. However, the timing of the introduction of such policies was powerfully influenced by short run macro-economic conditions, often serving as the triggering 
mechanism. This was certainly true of the 1890s depression, the Great War and postwar readjustment in the United States. It was true of the great depression for South African quotas in 1930, Brazilian quotas in 1934, and tough restrictions by Australia in 1930, New Zealand in 1931, and Canada in 1932. It was true of 1973/74 in Europe, when the first oil price shock and subsequent rising unemployment provoked the end of the guestworker era. And it was true of European toughening on asylum seekers in the late 1990s when host countries underwent a slowdown and falling employment rates.

Whether immigration has a big impact on labor markets in host countries or not (Williamson 1982, 1986, 1996, 1997; Hatton and Williamson 2004: Chps. 6 and 14), labor market conditions had a consistent influence on immigration policy, and they did so both through the absolute and relative income performance of unskilled workers. Real wage growth mattered most in the United States, nominal wage growth mattered most in Australia, while real wage levels mattered most in Brazil. In all cases, poor wage performance was associated with more restrictive policy. However, the most consistently significant explanatory variable is the ratio of the unskilled wage to per capita income, or of income near the bottom of the distribution to income in the middle. Rising inequality was associated with increasingly restrictive immigration policy. As we have seen, new immigrants tended to cluster at the bottom of the income distribution, a fact that was increasingly true as positive selection diminished over the century. Regardless of what else is included in the regression equation, this measure of labor's relative economic position stands up as an important influence on policy. Rising relative labor scarcity encouraged more open immigration policies; declining relative labor scarcity encouraged more restrictive immigration policies.

The evidence just summarized speaks to the indirect impact of immigration on policy by looking at absolute and relative wage performance in labor markets. What about the direct impact of immigration on policy? Perhaps the size and character of the current and expected future immigrant flow precipitated policy change, the latter serving to anticipate the labor market impact. Two variables serve to proxy direct immigration effects. One is a measure of quality of the immigrants - the real wage of urban workers in the source countries. Another is a measure of the quantity of the immigrants -- the foreign-born population share. Low and falling immigrant quality tended to precipitate immigration restrictions in 
Australia, Canada and the United States, even after controlling for other forces: policy in these countries anticipated the impact of rising numbers of low quality immigrants on unskilled wages and moved to exclude them. In addition, Argentina seems to have looked to the north across the Rio de la Plata to watch labor market events in Brazil, acting as if they knew that those events in that bigger neighbor would divert immigrants to or from Argentina's labor markets. Thus, rising relative and absolute wages in Brazil tended to produce more open policy in Argentina, and deteriorating Brazilian labor market conditions made Argentina close off immigration. In contrast, the United States was never responsive to competitors' immigration policies, presumably because it was too big to care and thus was a policy leader. For the smaller immigrating countries, however, policy abroad mattered a great deal.

The difference in ethnic composition between the current immigration flow and the foreign population stock seems to have had little bearing on policy. This is not the relationship that the popular literature favors: according to that view, a rising gap between the ethnic origins of previous immigrants -who had become residents and probably voting citizens -- and that of current immigrants, would serve to erode commitments to free immigration. We should be quick to add that we are speaking here almost entirely about immigrants of European ethnic origin. The US and other high-wage countries had already acted to exclude most Asians, and free Africans rarely tried to gain admission into the historically slavebased new world.

To summarize, while the size of the immigrant flow did not seem to have any consistent impact on new world policy up to 1930, its low and declining quality certainly did, provoking restriction. Racism and xenophobia do not seem to have been at work in driving the evolution of policy (which is not, of course, to deny that they existed). Rather, it was immigrant quality, labor market conditions and policies abroad -- especially those set by the economic leader, the United States -- that mattered most for policy. New world countries acted in a way that revealed an effort to defend the economic interests of their scarce factor, unskilled labor. 


\section{Coda}

This paper has pointed out a fact shared by the first global century up to World War I and the second global century since 1950. In both cases, the "quality" of high-wage host country immigrants declined as their numbers rose. This was reflected by declining skill and schooling attributes relative to host countries, and by a shift in their origins towards poorer sending countries. This declining quality was reflected in both cases by the declining ability of newcomers to compete on an equal footing with natives: thus, newcomers suffered increasingly large discounts in host country labor markets. No doubt this modern drift towards lower quality would be even more apparent if we were able to observe illegal immigrants.

It is also true that it was the changing source of the immigrants - from less poor to more poor regions - that was the main force driving down immigrant quality. In addition, the impact of changing source has been much larger in the half century since 1950 than in the half century before World War I. The reason is that the incoming immigrants by source exhibit far greater quality variance today, than the European immigrants did a century ago.

The paper then offers explanations for the drift from very positive to less positive and perhaps even negative selection. When dealing with selection, the immigration literature tends to stress income incentive (e.g. the Roy model) rather than cost and capital constraints. But it is the changes in selection that is at issue, not levels, and changes in selection can be best explained by changes in the costs of the move and the capital constraints on it. The poorest potential emigrants simply cannot find the resources to invest in a long distance move, but the poor can increasingly do so as the costs of the move fall for legal immigrants, as illegal smugglers become more efficient, and as potential emigrants devise ways to use family and kin as sources of funds. The constraint on the emigration of the poor is also loosened by two other important forces: economic development at home raises incomes of the poor and thus the surplus available for investment in a move; and pioneer migrants already in high-wage host countries can remit to 
help others invest in the move. Asia and Latin America have been one distant and poor source of OECD immigrants in the recent past, and Africa will be one in the near future.

The decline in immigrant quality played an important role in provoking hostile attitudes towards immigrants as the first global century unfolded, and it appears to be having the same role in the OECD today. Underlying fundamentals converted hostile anti-immigrant attitudes to a policy of quotas, bans and restrictions. However, from the 1890 s to the 1990 s, a triggering mechanism was essential before the fundamentals were converted to policy action. Macroeconomic crises offered that trigger. Will there be another trigger in our future? 


\section{References}

Antecol, H., Cobb-Clark, D. A. and Trejo, S. K. [2003a], "Immigration Policy and the Skills of Immigrants to Australia, Canada and the United States," Journal of Human Resources 38: 192 218.

Baily, S. L. [1983], "The Adjustment of Italian Immigrants in Buenos Aires and New York, 1870-1914," American Historical Review 88: 281-305.

Baker, M. and Benjamin, D. [1994], "The Performance of Immigrants in the Canadian Labor Market," Journal of Labor Economics 12: 455-71.

Borjas, G. J. [1987], "Self Selection and the Earnings of Immigrants,” American Economic Review 77: $531-53$.

--- [1992], "National Origin and the Skills of Immigrants in the Postwar Period," in G. Borjas and R. B. Freeman (eds.), Immigration and the Workforce: Economic Consequences for the United for the United States and Source Areas (Chicago: University of Chicago Press).

--- [1993], “Immigration Policy, National Origin, and Immigrant Skills: A Comparison of Canada and the United States,” in D. Card and R. B. Freeman (eds.), Small Differences that Matter: Labor Markets and Income Maintenance in Canada and The United States (Chicago: University of Chicago Press).

--- [1999], “The Economic Analysis of Immigration,” in O. Ashenfelter and D. Card (eds.), Handbook of Labor Economics, Vol. 3A (New York: North Holland).

Chickering, J. [1848], Immigration into the United States (Boston: Little Brown).

Chiquiar, D. and Hanson, G. H. [2002], "International Migration, Self-Selection, and the Distribution of Wages: Evidence from Mexico and the United States.” NBER Working Paper 9242, National Bureau of Economic Research, Cambridge, Mass. (September). 
Clark, X., T. J. Hatton and J. G. Williamson [2002], “Where Do US Immigrants Come From?

Policy and Sending Country Fundamentals.” NBER Working Paper 8998, National Bureau of Economic Research, Cambridge, Mass. (June).

Douglas, P. H. [1930], Real Wages in the United States, 1890-1926 (New York: Augustus Kelley, reprinted 1966).

Ferrie, J. P. [1999], Yankeys Now: Immigrants in the Antebellum United States, 1840-1860 (New York: Oxford University Press).

Goldin, C. [1994], "The Political Economy of Immigration Restriction in the United States, 1890 to 1921," in C. Goldin and G. D. Libecap (eds.), The Regulated Economy: A Historical Approach to Political Economy (Chicago: University of Chicago Press).

Green A., M. MacKinnon, and C. Minns [2002], "Dominion or Republic? Migrants to North America from the United Kingdom, 1870-1910,” Economic History Review 55: 666-96.

Habakkuk, H. J. [1962], American and British Technology in the Nineteenth Century (Cambridge: Cambridge University Press).

Hatton, T. J. [1997], “The Immigrant Assimilation Puzzle in Late Nineteenth Century America," Journal of Economic History 57: 34-62.

--- [2000], “How Much Did Immigrant “Quality” Decline in Late Nineteenth Century America?” Journal of Population Economics 13: 509-25.

Hatton, T. J., G. R. Boyer, and R. E. Bailey [1994] “The Union Wage Effect in Late Nineteenth Century Britain,” Economica 61: 435-56.

Hatton, T. J. and J. G. Williamson [1998], The Age of Mass Migration: An Economic Analysis (New York: Oxford University Press).

--- [2004], World Mass Migration: Two Centuries of Policy and Performance (ongoing).

Hendricks, L. [2002], “How Important is Human Capital for Development? Evidence from Immigrant Earnings,” American Economic Review 92: 198-219. 
Huntington, S. P. [2004], “Jose, Can You See?” Foreign Policy (March/April): 30-45.

Hvidt, C.[1975], Flight to America (New York: Academic Press).

Jenks, J. W. and W. J. Lauck [1926], The Immigration Problem (New York: Huebsch, $6^{\text {th }}$ ed.).

Kennedy, J. F. [1964], A Nation of Immigrants (New York: Harper Row).

Kirk, D. [1946], Europe's Population in the Interwar Years (Princeton, NJ: Princeton University Press for the League of Nations).

Klein, H. S. [1983], "The Integration of Italian Immigrants into the United States and Argentina: A Comparative Analysis,” American Historical Review 88: 306-29.

Mayda, A. M. [2003], "Who Is Against Immigration? A Cross-Country Investigation of Individual Attitudes Towards Immigrants.” Mimeo, Harvard University (January).

Minns, C. [2000], “Income, Cohort Effects, and Occupational Mobility: A New Look at Immigration to the United States at the Turn of the $20^{\text {th }}$ Century," Explorations in Economic History 37: 326-50.

O’Rourke, K. H. and R. Sinnott [2004], “The Determinants of Individual Attitudes Towards Immigration.” Mimeo. Trinity College Dublin (January).

O'Rourke, K. H. and J. G. Williamson [1999] Globalization and History: The Evolution of a Nineteenth-Century Atlantic Economy (Cambridge, Mass.: MIT Press).

Pope, D. and G. Withers [1994], "Wage Effects of Immigration in Late-Nineteenth Century Australia," in T. J. Hatton and J. G. Williamson eds., Migration and the International Labor Market, 1850-1939 (London: Routledge).

Rosenberg, N. [1967], “Anglo-American Wage Differences in the 1820s,” Journal of Economic History 27 (June): 221-9.

Stalker, P. [1994], The Work of Strangers: A Survey of International Labor Migration (Geneva: International Labor Organisation).

Timmer, A. and J. G. Williamson [1998], "Immigration Policy Prior to the Thirties: Labor Markets, 
Policy Interaction, and Globalization Backlash,” Population and Development Review 24 (December): 739-71.

United Nations [1979], Trends and Characteristics of International Migration since 1950

(New York: United Nations).

--- [2002], International Migration Report, 2002 (New York: United Nations).

US Department of Commerce [1975], Historical Statistics of the United States, Colonial Times to 1970 (Washington, D. C.: Bureau of the Census).

Wegge, S. A. [2002], “Occupational Self-Selection of European Emigrants: Evidence from Nineteenth Century Hesse-Cassel,” European Review of Economic History 6: 365-94.

Williamson, J. G. [1982], "Immigrant-Inequality Trade-Offs in the Promised Land: American Growth, Distribution and Immigration Prior to the Quotas," in B. Chiswick (ed.), The Gateway: U.S. Immigration Issues and Policies (Washington, D.C.: AEA Press).

--- [1986], “The Impact of the Irish on British Labor Markets During the Industrial Revolution,” Journal of Economic History 56 (September): 693-720.

--- [1996], "Globalization, Convergence and History," Journal of Economic History 56 (June): 1-30.

--- [1997], "Globalization and Inequality, Past and Present," World Bank Research Observer 12 (August): 117-35. 
Table 1

The Migrant Stock as a Percent of Population 1965-2000

\begin{tabular}{lrrrrrr}
\hline Year & 1965 & 1975 & 1985 & $1990 \mathrm{a}$ & $1990 \mathrm{~b}$ & 2000 \\
\hline World & 2.3 & 2.1 & 2.2 & 2.3 & 2.9 & 2.9 \\
Emigrant Regions & & & & & & \\
Africa & 2.5 & 2.7 & 2.3 & 2.5 & 2.6 & 2.1 \\
Asia & 1.7 & 1.3 & 1.4 & 1.4 & 1.6 & 1.4 \\
Latin Am. \& Carib. & 2.4 & 1.8 & 1.6 & 1.7 & 1.6 & 1.1 \\
& & & & & & \\
Immigrant Regions & & & & & & \\
North America & 6.0 & 6.3 & 7.8 & 8.6 & 9.8 & 13.0 \\
Europe & 2.2 & 2.7 & 3.0 & 3.2 & 6.7 & 7.7 \\
$\quad$ Western Europe & 3.6 & 4.9 & 5.8 & 6.1 & 8.6 & 10.3 \\
Oceania & 14.4 & 15.6 & 16.9 & 17.8 & 18.0 & 19.1 \\
& & & & & &
\end{tabular}

Source: Hatton and Williamson 2004, Table 10.1. Note: There are differences of definition in the figures for $1965-$ 90a and 1990b-2000. The most important is due to the break up of the Soviet Union, which is included with Europe for the earlier years but the reclassified republics added about 27 million to the world international migrant stock in 2000 .

Table 2

Composition of US Immigration by Sending Region 1951-2000 $(\%$ of total)

\begin{tabular}{lrrrrr}
\hline Region of Origin & $\mathbf{1 9 5 1 - 6 0}$ & $\mathbf{1 9 6 1 - 7 0}$ & $\mathbf{1 9 7 1 - 8 0}$ & $\mathbf{1 9 8 1 - 9 0}$ & $\mathbf{1 9 9 1 - 2 0 0 0}$ \\
\hline Europe & 52.7 & 33.8 & 17.8 & 10.3 & 14.9 \\
$\quad$ West & 47.1 & 30.2 & 14.5 & 7.2 & 5.6 \\
$\quad$ East & 5.6 & 3.6 & 3.3 & 3.1 & 9.4 \\
Asia & 6.1 & 12.9 & 35.3 & 37.3 & 30.7 \\
Americas & 39.6 & 51.7 & 44.1 & 49.3 & 49.3 \\
$\quad$ Canada & 15.0 & 12.4 & 3.8 & 2.1 & 2.1 \\
$\quad$ Mexico & 11.9 & 13.7 & 14.2 & 22.6 & 24.7 \\
$\quad$ Caribbean & 4.9 & 14.2 & 16.5 & 11.9 & 10.8 \\
$\quad$ Central America & 1.8 & 3.1 & 3.0 & 6.4 & 5.8 \\
$\quad$ South America & 3.6 & 7.8 & 6.6 & 6.3 & 5.9 \\
Africa & 0.6 & 0.9 & 1.8 & 2.4 & 3.9 \\
Oceania & 0.5 & 0.8 & 0.9 & 0.6 & 0.6 \\
Total (000's) & & & & & \\
\hline
\end{tabular}

Source: Hatton and Williamson 2004, Table 10.2. Notes: National origin based on country of last residence. Totals include 2.7 million former illegal aliens receiving permanent resident status under the Immigration Reform and Control Act 1986. Of these, 1.3 million fall in the decade 1981-1990 and 1.4 million in the decade 1991-2000. 
Table 3

Education of Sending Country Stayers and of Its Emigrants in Host Countries c1990

\begin{tabular}{lccc}
\hline Region (no. of sending countries) & \multicolumn{3}{c}{ Years of Schooling } \\
\cline { 2 - 4 } & $\begin{array}{l}\text { Stayers in the } \\
\text { Sending Countries }\end{array}$ & $\begin{array}{c}\text { Migrants in the } \\
\text { Host Countries }\end{array}$ & $\begin{array}{c}\text { Difference } \\
\text { (Migrants-Stayers) }\end{array}$ \\
\hline Africa (4) & 4.6 & 15.4 & 10.8 \\
Mexico (1) & 6.3 & 7.5 & 1.2 \\
Caribbean and Central America (14) & 5.4 & 11.2 & 5.8 \\
South America (10) & 5.9 & 12.5 & 6.6 \\
Asia (15) & 5.8 & 14.4 & 8.6 \\
Eastern Europe, the Balkans and Turkey (3) & 7.8 & 12.6 & 4.8 \\
Total (47) & 5.7 & 12.9 & 7.2
\end{tabular}

Source and Notes: Based on Hendricks (2002: Table B1). All figures are unweighted averages. The stayer column is based on Barro-Lee while the migrant column is based on OECD censuses around 1990. The two columns use country observations only if they supply both the stayer and the migrant information.

Table 4

The Occupations of US Immigrants, 1820-1898

\begin{tabular}{lllllllll}
\hline Occupation & $\mathbf{1 8 2 0 -}$ & $\mathbf{1 8 3 2 -}$ & $\mathbf{1 8 4 7 -}$ & $\mathbf{1 8 5 5 -}$ & $\mathbf{1 8 6 5 -}$ & $\mathbf{1 8 7 3 -}$ & $\mathbf{1 8 8 1 -}$ & $\mathbf{1 8 9 4 -}$ \\
& $\mathbf{1 8 3 1}$ & $\mathbf{1 8 4 6}$ & $\mathbf{1 8 5 4}$ & $\mathbf{1 8 6 4}$ & $\mathbf{1 8 7 3}$ & $\mathbf{1 8 8 0}$ & $\mathbf{1 8 9 3}$ & $\mathbf{1 8 9 8}$ \\
\hline Skilled & 61 & 40 & 24 & 36 & 31 & 30 & 24 & 30 \\
Farmers & 23 & 33 & 33 & 23 & 18 & 18 & 14 & 12 \\
Unskilled & 16 & 26 & 43 & 41 & 51 & 48 & 60 & 55 \\
Miscellaneous & -- & -- & -- & 0 & 1 & 5 & 3 & 3 \\
& 70 & 62 & 59 & 58 & 62 & 63 & 61 & 57 \\
Percent male & 70 & &
\end{tabular}


Table 5

Quality Proxies for the US Population 1870-1930

\begin{tabular}{lllll}
\hline & $\begin{array}{l}\text { Enrollment } \\
\text { Rates Per 100 } \\
\text { Population }\end{array}$ & $\begin{array}{l}\text { Attendance } \\
\text { Rates per } \\
\text { Student }\end{array}$ & $\begin{array}{l}\text { \% 17 Year olds } \\
\text { Graduating } \\
\text { High School }\end{array}$ & $\begin{array}{c}\text { Illiteracy } \\
\text { Rate }\end{array}$ \\
\hline & & & & \\
1870 & 48.4 & 78.4 & 2.0 & 20.0 \\
1880 & 57.8 & 81.1 & 2.5 & 17.0 \\
1890 & 54.3 & 86.3 & 3.5 & 13.3 \\
1900 & 50.5 & 99.0 & 6.3 & 10.7 \\
1910 & 59.2 & 113.0 & 8.6 & 6.7 \\
1920 & 64.3 & 121.2 & 16.3 & 4.3 \\
1930 & 69.9 & 151.7 & 28.8 & \\
\hline
\end{tabular}

Source: US Department of Commerce 1975: pp. 370, 375-6, 379-80, 382.

Table 6

Skill Premia in the United States and Europe 1890

\begin{tabular}{lllll}
\hline & $\begin{array}{l}\text { United } \\
\text { States }\end{array}$ & $\begin{array}{l}\text { Great } \\
\text { Britain }\end{array}$ & $\begin{array}{l}\text { France/ } \\
\text { Belgium }\end{array}$ & $\begin{array}{l}\text { Germany/ } \\
\text { Switzerland }\end{array}$ \\
\hline $\begin{array}{l}\text { Premium for semi-skilled over } \\
\text { unskilled }\end{array}$ & 28.4 & 16.1 & 25.2 & 17.9 \\
$\begin{array}{l}\text { Premium for skilled over } \\
\text { unskilled }\end{array}$ & 53.0 & 32.6 & 63.1 & 35.2 \\
\hline
\end{tabular}

Source: Hatton, Boyer and Bailey (1994). Notes: These are the coefficients from a regression of log earnings for male household heads on age, age squared industry dummies (that differ between Europe and the US) and skill by country dummies. All the coefficients reported here are significant at the 5 percent level. 
Figure 9.1

Emigration from Europe, 1881-1939

(five-year averages)

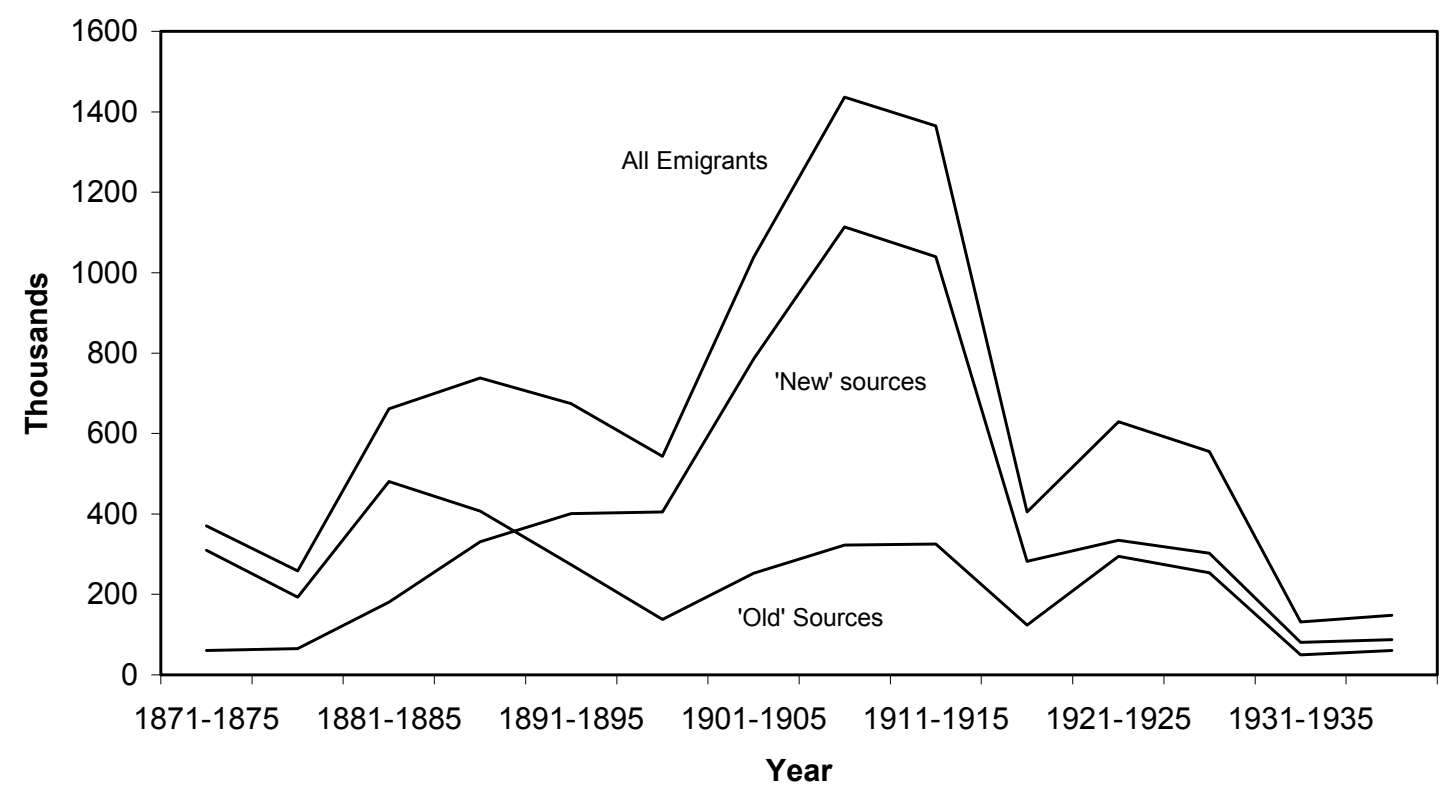

Source: Kirk (1946: 289). 